Anna Polańska

Akademia Sztuk Pięknych w Gdańsku, Uniwersytet Gdański

ORCID ID: 0000-0002-8114-3008
OBLICZA WOJNY

TOM 5 - MIASTO I WOJNA

ŁÓDŹ2021 •ISBN 978-83-8220-699-9• • 3.319-340

https://doi.org/10.18778/8220-699-9.18

\title{
"MIASTO-RUINA" OBRAZ POWOJENNEGO GDAŃSKA W FOTOGRAFIACH KAZIMIERZA LELEWICZA
}

Streszczenie. Metropolie i miasta od zawsze fascynowały artystów, również tych posługujących się fotografią. Druga wojna światowa przyniosła nieznany dotąd obraz miasta-ruiny. $\mathrm{Ci}$, co przeżyli zagładę, podejmowali próbę zobrazowania zniszczeń. Fotografie miały być świadectwem okrucieństwa wojny, a po latach stały się także materiałem wykorzystywanym przez badaczy z wielu dyscyplin naukowych. Tu wyłania się specyfika ukazywania ruin w kontekście zdjęcia, które może być dokumentem, ale także dziełem sztuki. Ruiny stały się dla twórców wyzwaniem reporterskim i artystycznym. Obrazy zniszczonych miast zaczęły być wystawiane w muzeach oraz galeriach, i to nie tylko w pierwszych latach od zakończenia drugiej wojny światowej. W Polsce symptomatyczny jest sposób ukazywania zniszczeń Warszawy w porównaniu z miastami z terenów Ziem Odzyskanych. Stolica stała się symbolem dramatu całego kraju. Często zestawiano obraz miasta sprzed 1939 r. z obrazem wojennych zniszczeń. Trochę inny przekaz miały fotografie zrujnowanych: Gdańska, Szczecina i Wrocławia. W miastach tych szukano dowodów polskości, na wielowiekową tradycję i historyczną przynależność do Polski. Widoki zniszczonych miast zestawiano z obrazem odbudowy kraju, akcentując nowy, geopolityczny porządek. Szacuje się, że podczas drugiej wojny światowej zabytkowe centrum Gdańska zostało zniszczone w ok. 90 procentach. Do tak zrujnowanego miasta jesienią 1945 r. przybył z Wilna Kazimierz Lelewicz (1896-1986), z wykształcenia inżynier i artysta fotograf. Rozpoczął długoletni proces dokumentowania zniszczeń i odbudowy Gdańska. W fotografiach K. Lelewicza uderzające jest zestawienie obrazu miasta-ruiny, wymarłej, autonomicznej przestrzeni, z miastem-budową, w którym tętni życie. Takie połączenie wizerunków tkanki miejskiej ma bardzo symboliczną i alegoryczną wymowę. Warto również i w tym kontekście podjąć rozważania nad obrazem ruiny oraz sposobem jej interpretacji przez Kazimierza Lelewicza. Już sam temat prowokuje do rozpatrywania motywu ruiny w dyskursie pamięci bądź zapomnienia.

Słowa kluczowe: Kazimierz Lelewicz, zniszczenie i odbudowa Gdańska, fotografia ruin, miasto po drugiej wojnie światowej 
Druga wojna światowa przyniosła nieznany dotąd obraz zniszczenia miast. Dzięki m.in. fotografii rejestrowano destrukcję tkanki miejskiej, a później jej odbudowę lub zmiany wynikające z nowych koncepcji urbanistycznych. Wielu artystów, którzy przeżyli zagładę, podejmowało próbę zobrazowania zniszczeń. W Polsce dokumentowano najliczniej widoki zniszczonej stolicy oraz miast z terenów Ziem Odzyskanych ${ }^{1}$. Można zauważyć pewną różnicę w dyskursie na temat obrazu miasta-ruiny, gdy dotyczył on Warszawy oraz takich miast, jak np. Gdańsk, Szczecin czy Wrocław. Stolica stała się symbolem dramatu całego kraju. Porównywano te same widoki sprzed 1939 r. z obrazem powojennej destrukcji. Trochę inny przekaz miały fotografie zniszczonych miast należących przed wojną do Niemiec. W celu budowania po zakończeniu drugiej wojny światowej nowego wizerunku Polski władze komunistyczne posługiwały się różnymi formami propagandy w stosunku do Ziem Zachodnich i Północnych Polski ${ }^{2}$ Jedną z nich było wykorzystanie idee fotografii ojczystej, która została reaktywowana niemal natychmiast po wygaśnięciu walk³ ${ }^{3}$ Początki fotografii ojczystej w Polsce sięgają drugiej połowy lat trzydziestych XX w., a jej bezspornym propagatorem był Jan Bułhak ${ }^{4}$. W celu odróżnienia fotografii ojczystej od np. krajoznawczej, pejzażowej czy reporterskiej przygotowano system zasad i wytycznych dla obrazowania kraju w „duchu narodowym”, sięgając z jednej strony do tradycji (motywy szlacheckie, folklor, wieś, zabytki, związki człowieka z naturą), a z drugiej strony do rozwoju i industrializacji państwa (budowa gdyńskiego portu, hale produkcyjne, fabryki), co miało swoje przełożenie na okres po $1945 \mathrm{r}$. Wizualny przekaz zniszczeń wojennych oraz

${ }^{1}$ J. JASIŃSKI, Kwestia pojęcia Ziemie Odzyskane, [w:] Ziemie Odzyskane - Ziemie Zachodnie i Pótnocne 1945-2005. 60 lat w granicach państwa polskiego, red. A. SAKSON, Poznań 2006, s. 15-25.

2 R. Domke, Ziemie Zachodnie i Pótnocne Polski w propagandzie lat 1945-1948, Zielona Góra 2010.

3 M. Szymanowicz, Zaburzona epoka. Polska fotografia artystyczna w latach 1945-1955, Poznań 2016, s. 67.

${ }^{4} \mathrm{Na}$ temat fotografii ojczystej, vide: J. BUŁHAK, Fotografia ojczysta. Rzecz o uspotecznianiu fotografi, Wrocław 1951; A. SовотA, Szlachetność techniki. Artystyczne dylematy fotografii w XIX i XX wieku, Warszawa 2001, s. 89-92; IDEM, Jan Buthak i koncepcje narodowości fotografii, [w:] Jan Buthak (1876-1950) fotografik, [katalog wystawy Muzeum Narodowe w Warszawie, 14 grudnia 2006-11 lutego 2007], red. D. JACKIEWICZ, A. MASŁOWSKA, Warszawa 2007, s. 177-197; M. SZyMANOWICZ, Byliśmy jesteśmy będziemy. Fotografia ojczysta po II wojnie światowej, [w:] Interpretować fotografię. Materiaty z sesji naukowej zorganizowanej przez Oddziat Warszawski Stowarzyszenia Historyków Sztuki i Fundację, Ars Auro Prior”, red. M. WróblewsKa, Z. Jurkowlaniec, Warszawa 2009; IDEM, Zaburzona epoka..., s. 67-130. 
Ziem Odzyskanych idealnie nadawał się dla władzy do manipulowania historią w celu legitymizacji tych ziem w nowym, powojennym układzie społeczno-politycznym. Chodziło o akcentowanie polskich motywów z przeszłości związanych ze Słowiańszczyzną i państwem piastowskim, przy jednoczesnym zacieraniu, a wręcz wymazywaniu wszystkiego, co miało związek z okupantem niemieckim. Idea fotografii ojczystej, jak pisze Maciej Szymanowicz: „była silnie osadzona w tradycji narodowo-patriotycznej, a rejestrację ruin traktowano wręcz jako obowiązek"5, i dodaje, że motyw ruiny posłużył nowym władzom do stworzenia ideologicznego mitu odbudowy, szczególnie gdy propagowano zestawy zdjęć polegające na zderzeniu zrujnowanego miasta z odbudowywanym $^{6}$. Należy pamiętać, że fotografia ojczysta opierała się na estetycznych założeniach piktorializmu. Kierunku w fotografii powstałego pod koniec XIX w., który odwołując się w warstwie tematycznej, stylistycznej i estetycznej do malarstwa i grafiki, miał plasować fotografię wśród sztuk plastycznych i tym samym wpisywać ją w nurt fotografii artystycznej

Wymiar symboliczny i alegoryczny obrazu ruiny umiejscawia ów motyw w kręgu historii sztuki. Oglądając fotograficzny zapis zrujnowanego miasta, często napotykamy na dwoistość przekazu. Z jednej strony patrzymy na zdjęcie jak na dokument, z drugiej dostrzegamy jego walory estetyczne. Ruiny stały się dla fotografików wyzwaniem reporterskim, ale również artystycznym. Powstawały archiwa, które eksponowano w muzeach i galeriach. Najbardziej nośne były wystawy poświęcone stolicy. Jeszcze w maju 1945 r. w Muzeum Narodowym w Warszawie zorganizowano pokaz pt. Warszawa oskarża, na którym prezentowano zdjęcia Zofii Chomentowskiej, Janiny Mierzeckiej, Marii Chrząszczowej i Tadeusza Przypkowskiego ${ }^{8}$. W tym samym miejscu w lutym 1946 r. otwarto

5 M. Szymanowicz, Budowniczowie "Świata Fotografii”. Polska fotografia drugiej potowy lat 40. XX wieku, [katalog wystawy, maj-czerwiec 2009, Centrum Kultury „Zamek” w Poznaniu], Poznań 2009, s. 9.

${ }^{6}$ Ibidem, s. 10.

7 Na temat piktorializmu, vide: N. Rosenblum, A World History of Photography, New YorkLondon 1997; A. SobotA, Szlachetność techniki...; P. Prodger, Impressionist Camera. Pictorial Photography in Europe, 1888-1918, London 2006; M. SZYMANOWICZ, W kregu fotografii piktorialnej, [w:] Jan Buthak (1876-1950)..., s. 128-175.

${ }^{8}$ Warszawa oskarża. Przewodnik po wystawie urzadzonej przez Biuro Odbudowy Stolicy wespót z Muzeum Narodowym $w$ Warszawie [Warszawa, maj-czerwiec 1945], Ministerstwo Kultury i Sztuki i Ministerstwo Odbudowy Kraju, Warszawa 1945; A. PrZeźDZIeCKa-KujaŁowiCz, „Warszawa oskarża”. Pierwsza powojenna wystawa Muzeum Narodowego w Warszawie, „Spotkania z Zabytkami. Kultura, Tradycje, Pamiątki” 2018, nr 11-12, s. 24-31; M. SzYMANowiCz, Zaburzona epoka..., s. 78. 
wystawę pt. Warszawa 1945 roku w obrazach fotograficznych Jana Buthaka ${ }^{9}$. Fotografie z obrazami zrujnowanych miast wystawiano też wiele lat po zakończeniu wojny. Przykładem jest tu ekspozycja w warszawskiej Zachęcie z 1969 r. pt. Warszawa 1945 w fotografii Leonarda Sempolińskiego ${ }^{10}$.

Ruiny można poddać rekonstrukcji, odbudowie lub totalnemu wymazaniu z tkanki miejskiej, co ma znaczenie w dyskursie pamięci historycznej bądź zapomnienia ${ }^{11}$. Doskonale to widać na przykładzie zdjęć powojennego Gdańska wykonanych przez Kazimierza Lelewicza. Przez ingerencję w obraz miasta-ruiny doprowadzono do usunięcia śladów wojennych zniszczeń, a jednocześnie przez dokumentację owych działań „wykreowano” miasto na nowo, co bez wątpienia miało swoje uwarunkowania polityczne i społeczne.

Zabudowa miejska Gdańska uległa destrukcji w marcu 1945 r. m.in. przez naloty alianckie i radzieckie, ostrzał artylerii i walki w samym mieście. Od końca marca, po wyzwoleniu, w mieście dochodziło do celowych podpaleń i dewastacji ${ }^{12}$. Na niezabezpieczone budynki zaczęły z czasem działać także warunki atmosferyczne (opady, wiatr, niska temperatura) i w konsekwencji prowadziło to do dalszych zniszczeń. Zanim rozpoczęły się planowe prace konserwatorskie, odbywało się niekontrolowane odgruzowywanie miasta oraz dochodziło do kradzieży materiałów budowlanych ${ }^{13}$. Wielkość zniszczeń historycznego centrum Gdańska szacuje się najczęściej na jakieś 90 procent $^{14}$.

9 Wystawa była eksponowana także w Łodzi, Radomiu, Bydgoszczy, Poznaniu i Toruniu, vide: M. Plater-Zyberek, G. Dreścik, Kalendarium, [w:] Jan Buthak (1876-1950)..., s. 115.

${ }^{10}$ Warszawa 1945 w fotografii Leonarda Sempolińskiego, [katalog wystawy, Zachęta Centralne Biuro Wystaw Artystycznych, wrzesień 1969, Warszawa], red. B. Mitschein, Warszawa 1969.

${ }^{11} \mathrm{Na}$ temat pamięci historycznej, vide: M. KuLA, Między przesztością a przysztością. O pamięci, zapominaniu i przewidywaniu, Poznań 2004.

12 B. OKONIEWSKA, Refleksje nad rokiem 1945, [w:] Gdańsk 1945. Materiaty z sesji naukowej odbytej w dniu 30 marca 1995 r., pod red. prof. dr. hab. Mariana Mroczki, red. E. RuSAK, Gdańsk 1995, s. 7-17.

13 M. GAWLICKI, Zabytkowa architektura Gdańska w latach 1945-1951. Ksztattowanie koncepcji konserwacji i odbudowy, Gdańsk 2012, s. 50-51.

${ }^{14}$ Nadal dane statystyczne co do skali zniszczeń w Gdańsku nie są precyzyjne. Najbardziej zostało zniszczone Śródmieście, a wskaźnik w wysokości 90 procent strat najprawdopodobniej jest wynikiem sprawozdania z 1946 r. Gdańskiej Dyrekcji Odbudowy, vide: Archiwum Państwowe w Gdańsku, Sprawozdanie GDO za okres 1 maja 1945 - 1 września 1946, 1180/12, k. 11. Informacje o takiej skali zniszczeń występują w opracowaniach na temat odbudowy Gdańska, cf:: J. STANKIEWICZ, B. SzERMER, Gdańsk. Rozwój urbanistyczny i architektoniczny oraz powstanie zespotu Gdańsk-Sopot-Gdynia, Warszawa 1959, s. 275; M. STRYCZYŃSKI, Gdańsk w latach 1945-1948. Odbudowa organizmu miejskiego, Gdańsk 1981, s. 32; W. HeWELT, Danzig, ein europäisches Kulturdenkmal, Lübeck 1988, s. 112; 
Do tak zrujnowanego miasta jesienią 1945 r. przybył Kazimierz Lelewicz ${ }^{15}$. $\mathrm{Z}$ wykształcenia był inżynierem i fotografem artystą. Urodził się 15 grudnia 1896 r. w Lubartowie ${ }^{16}$. W 1915 r. ukończył w Warszawie Szkołę Mechaniczno-Techniczną im. Stanisława Rotwanda i Hipolita Wawelberga jako inżynier budownictwa kolejowego. W następnym roku odbył kurs specjalny w oficerskiej Wyższej Szkole Wojennej Wydziału Budownictwa w Moskwie. W latach 19191921 pracował przy budowie linii kolejowej Rejowiec-Bełżec na Lubelszczyźnie, po czym od 1921 r. do zakończenia drugiej wojny światowej związany był z Wilnem. W okresie tym pracował jako projektant linii i obiektów kolejowych w Okręgowej Dyrekcji Polskich Kolei Państwowych w Wilnie. W czasie okupacji był zatrudniony w Biurze Projektowania Budynków Przemysłowych i prowadził własną pracownię fotograficzną. Należał do ruchu oporu Armii Krajowej. Po przybyciu do Gdańska w 1945 r. zgłosił się do pracy w PKP, ale ze względu na zły stan zdrowia 12 sierpnia 1947 r. przeszedł na emeryturę. Następnie 1 marca 1949 r. został zatrudniony jako kontraktowy wykładowca i organizator Studium Fotograficznego w Politechnice Gdańskiej, gdzie pracował do początku lat siedemdziesiątych XXw.

Rozwój artystyczny i kariera zawodowa K. Lelewicza jako fotografika ${ }^{17}$ sięgają czasów wileńskich, choćjak sam wspomina - pierwszy aparat otrzymał od rodziców

W. GruszKowski, Zniszczenie Śródmieścia Gdańska i początki odbudowy, [w:] Gdańsk 1945..., s. 21; M. GAWLICKI, op. cit., s. 19-23; J. FrIEDRICH, Odbudowa Gtównego Miasta w Gdańsku w latach 19451960, Gdańsk 2015, s. 24-27.

15 Sam artysta podawał różne daty przybycia do Gdańska w 1945 r. W Ankiecie personalnej z 30 listopada 1950 r. widnieje 23 października (Archiwum Politechniki Gdańskiej, Ankieta personalna Kazimierz Lelewicz, karty bez paginacji), w życiorysie z 1 grudnia 1953 r. jest data 18 listopada (Archiwum Związku Polskich Artystów Fotografików (dalej: AZPAF), Teczka osobowa nr 8 Kazimierz Lelewicz, Życiorys, karty bez paginacji oraz J. Piwowarski, Wileńskie środowisko fotograficzne w okresie międzywojennym, Częstochowa 2016, s. 120). Natomiast Janusz Ciemnołoński w artykule poświęconym artyście podaje jako moment przybycia K. Lelewicza do Gdańska trzecią dekadę września, vide: J. CiemnOŁOŃSKI, Kręte drogi Kazimierza Lelewicza do rumowiska Gdańska, „Z Historii Politechniki Gdańskiej...” 1995, nr 4, s. 20.

${ }^{16}$ Dane biograficzne zostały opracowane na podstawie: AZPAF, Teczka osobowa nr 8; J. PIWOWARSKI, op. cit.; Fotografowie 1946-2006. Stownik biograficzny fotografów polskich (cztonków ZPAF), red. Z. Jurkowlaniec, W.T. Nowotka, M. Wideryński, Warszawa 2006; Odbudowa. Fotografie Kazimierza Lelewicza, red. J. DomINICZAK, M. GAWLICKI, J.W. WOŁODŹKO, Gdańsk-Toruń 2014.

17 Według nomenklatury Jana Bułhaka fotografik to inaczej artysta-fotograf. Określenie to, wprowadzone w międzywojniu przez J. Bułhaka, miało wyróżniać twórców zajmujących się fotografią artystyczną od fotografów rzemieślników czy fotoreporterów. W 1947 r. zarejestrowano podległy MKiS 
w wieku szkolnym. Kazimierz Lelewicz w latach 1923-1926 odbył studia artystyczne na Uniwersytecie Wileńskim im. Stefana Batorego. Tam pobierał nauki malarstwa m.in. u Mariana Kuleszy, Tadeusza Rostworowskiego i Ferdynanda Ruszczyca, historii sztuki uczył go Marian Morelowski, a fotografii Jana Bułhak, jedna z najważniejszych postaci dla środowiska fotograficznego, której twórczość i poglądy mocno zaważyły na estetyce polskiej fotografii artystycznej sprzed drugiej wojny światowej i po niej. Dodajmy, że pierwszym nauczycielem K. Lelewicza był wileński fotograf Jan Kuruszy-Worobjew. Kazimierz Lelewicz zaangażował się w kreowanie życia fotograficznego w Polsce. W 1927 r. współzakładał Wileńskie Towarzystwo Miłośników Fotografii, był m.in. jego wiceprezesem, a rok później współtworzył Fotoklub Wileński (1928). Jak podał Jerzy Piwowarski, twórca był również członkiem najbardziej elitarnego towarzystwa w międzywojniu, utworzonego w 1929 r. Fotoklubu Polskiego ${ }^{18}$. Sam artysta natomiast nie przyznawał się do owego członkostwa. W obszernej dokumentacji zawartej w Teczce osobowej Kazimierza Lelewicza nie ma żadnej informacji o jego przynależności do Fotoklubu Polskiego ${ }^{19}$. Potwierdza to nota dotycząca powstania Związku Polskich Artystów Fotografików (dalej: ZPAF) zawarta na stronie stowarzyszenia ${ }^{20}$. Niemniej artysta brał udział w licznych wystawach krajowych i zagranicznych, zdobywając nagrody i wyróżnienia. Zajmował się propagowaniem dziedziny, prowadząc kursy, a w 1928 r. wygłosił dziesięć odczytów na temat fotografii w rozgłośni Radia Wileńskiego, podobnie jak to czynił wspomniany J. Bułhak. Po wojnie K. Lelewicz kontynuował swój rozwój artystyczny i zaangażowanie w budowanie nowych struktur życia fotograficznego. W 1947 r. został jednym z pierwszych założycieli (legitymacja nr 8) ZPAF i był delegatem związku na teren gdański. W tym samym roku współzałożył Gdańskie Towarzystwo Fotograficzne, którego był

Związek Polskich Artystów Fotografików (dalej: ZPAF). Do tego czasu istniały liczne stowarzyszenia, których członkowie nie mogli oficjalnie uprawiać zawodu artysty na wzór np. plastyków.

18 Według danych zebranych przez Jerzego Piwowarskiego nazwisko Kazimierza Lelewicza widnieje w spisie członków Fotoklubu Polskiego jedynie za 1930 r., por. J. Piwowarski, Fotoklub Polski (1929-1939), [w:] IX Międzynarodowe Targi Fotografii i Obrazu XIII Ogólnopolski Zjazd Fotografów. Materiaty sesji naukowo-technicznej, POLFOTO'2000, Międzyzdroje, 4-9 kwietnia 2000 r., red. P. NoWAK, Wrocław 2000, s. 153.

19 AZPAF, Teczka osobowa nr 8.

${ }^{20}$ Fragment preambuły statutu Związku stanowi, że „Związek opiera się na tradycjach Fotoklubu Polskiego istniejącego w latach 1929-1939 i jest spadkobiercą jego idei artystycznych" przy nazwisku Kazimierza Lelewicza nie ma informacji, że należał do Fotoklubu Polskiego - Historia powstania Zwiazku Polskich Artystów Fotografików, https://zpaf.pl/wladze-naczelne/zalozyciele/ (dostęp: 20 XI 2020). 
pierwszym prezesem. Od 1957 r. należał do Międzynarodowej Federacji Sztuki Fotograficznej FIAP, otrzymując rok później tytuł wybitnego artysty „excellence” (EFIAP). Nadal brał udział, odnosząc sukcesy, w licznych wystawach, a także publikował w pierwszym powojennym czasopiśmie branżowym „Świat Fotografii”. Za swoją działalność artystyczną i zawodową otrzymał liczne nagrody i wyróżnienia (m.in. Srebrny Krzyż Zasługi 1955, Odznaka „Zasłużony Działacz Kultury” 1964, Nagroda Wojewody Gdańskiego 1976).

Kazimierz Lelewicz po raz pierwszy odwiedził Gdańsk w $1921 \mathrm{r}^{21}$ A więc znał miasto jeszcze sprzed wojny i mógł ocenić ogrom zniszczenia, jaki dotknął tkankę miejską pod koniec drugiej wojny światowej. Fotograf wraz z żoną Marią (artystką rzeźbiarką, również absolwentką Uniwersytetu Wileńskiego im. Stefana Batorego) byli repatriantami, którzy związali się z Gdańskiem do końca swych dni. Kazimierz Lelewicz zmarł 1 października 1986 r., a Maria Lelewicz 27 stycznia 1991 r., oboje są pochowani na Komunalnym Cmentarzu Centralnym „Srebrzysko”.

Kazimierz Lelewicz po przyjeździe do Gdańska bardzo szybko rozpoczął dokumentację zniszczeń Starego Miasta, a później jego odbudowę. Było to m.in. efektem współpracy z wojewódzkim konserwatorem zabytków Janem Borowskim $^{22}$ oraz z kierownikiem Wydziału Kultury MRN Janem Kilarskim ${ }^{23}$, odpowiedzialnym za zabezpieczenie dóbr kulturalnych w Gdańsku, a także kontaktów zawodowych z profesorami Politechniki Gdańskiej, którzy byli zaangażowani w plany zabezpieczania i odbudowy miasta. Marcin Gawlicki w kontekście powojennej odbudowy Gdańska podzielił materiał fotograficzny K. Lelewicza na trzy zasadnicze okresy. Pierwszy dotyczy 1945 r. i przedstawia obraz zniszczeń centrum historycznego miasta; drugi odnosi się do lat 19461949, kiedy to odgruzowywano miasto oraz zabezpieczano obiekty, poddając je pracom konserwatorskim i adaptacyjnym; trzeci zaś to lata 1950-1960, gdy

${ }^{21}$ T. DANISZEwSKI, Kazimierz Lelewicz (1896-1986), „Kalendarz Gdański na Rok 1989”, Gdańsk 1988, s. 174; K. LeLEWICZ, Wojna wielkość karleje - pokojem wzrasta, „Kalendarz Gdański na Rok 1985", Gdańsk 1984, s. 279.

${ }^{22}$ Jan Borowski przed wojną był związany z wileńskim środowiskiem artystycznym, po wojnie kontynuował współpracę z twórcami, także z fotografikami. W 1948 r. pełnił funkcję członka jury największego po 1945 r. ogólnopolskiego konkursu fotograficznego zorganizowanego przez Gdańskie Towarzystwo Fotograficzne, Wystawa Sztuk Plastycznych, [katalog wystawy, 27 VI - 15 VIII 1948], Sopot 1948, s. 49; J. CiemnoŁoński, Borowski Jan, [w:] Polski Stownik Biograficzny Konserwatorów Zabytków, http://www.serwer 1363362.home.pl/SKP/ (dostęp: 20 XI 2020).

${ }_{23}$ M. KILARSKI, Kilarski Jan, [w:] Polski Stownik Biograficzny Konserwatorów Zabytków, http:// www.serwer1363362.home.pl/SKP/ (dostęp: 20 XI 2020). 
trwała odbudowa miasta ${ }^{24}$. Kazimierz Lelewicz nie był jedynym fotografem, który „portretował” Gdańsk tuż po zakończeniu działań wojennych ${ }^{25}$, ale mając oficjalne pozwolenia konserwatorskie, mógł robić zdjęcia z miejsc, do których inni nie mieli wstępu, np. z dachu Wielkiej Zbrojowni, Ratusza Głównego czy bazyliki Mariackiej. W efekcie jego zdjęcia ukazują zniszczenia z dużych wysokości, co może przypominać rzuty planu miasta, na których widzimy jedynie zarys fundamentów i rumowisko.

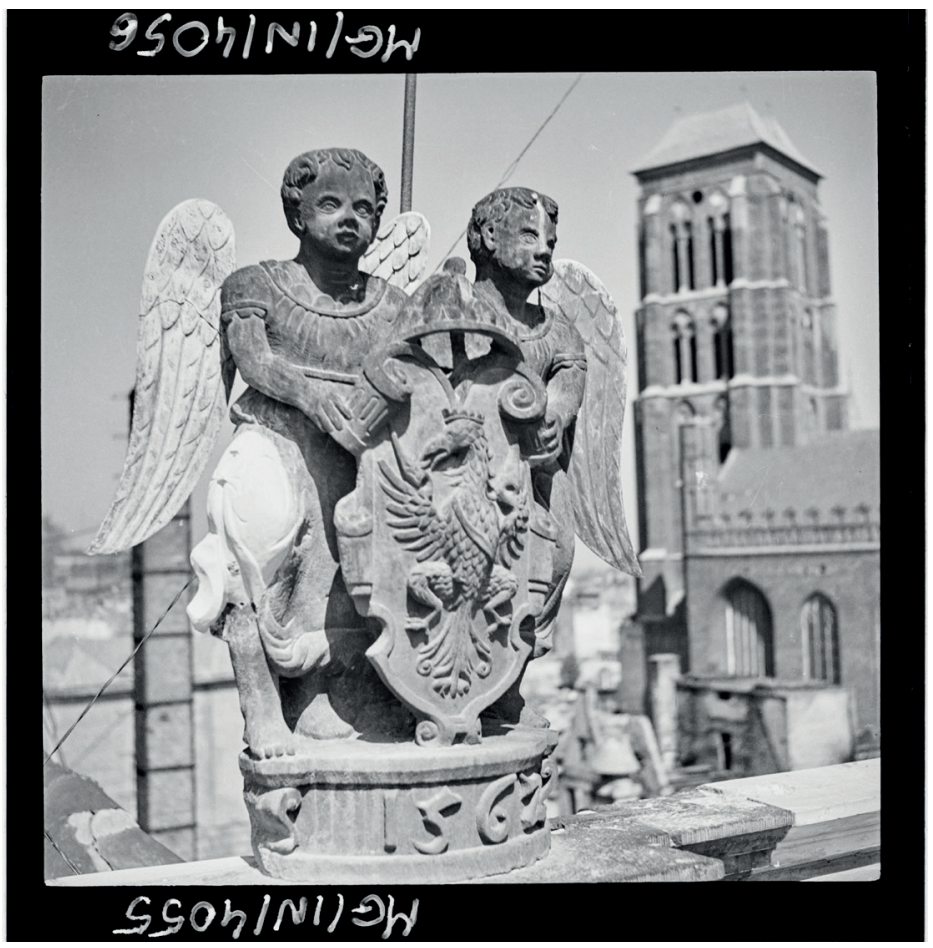

Ryc. 1. Negatyw czarno-biały ukazuje detal architektoniczny znajdujący się na attyce ratusza Głównego Miasta Gdańska. Detal przedstawia dwa anioły (po uzupełnieniu ubytków), trzymające kartusz herbowy. W tle po prawej stronie widoczna wieża kościoła Mariackiego. Czas powstania fotografii: po 1945 r., fot. Kazimierz Lelewicz, zbiory Muzeum Gdańska, numer inwentarzowy: MG/IN/4055 (źródło opisu: http://dziedzictwo-gdansk.pl/record/-/record/display/manifestation/

RECORD20043/3892c4bc-3f7c-4e06-b41b-535ab52f3196/solr/0/12/0/1/score/DESC, dostęp: 12 X 2020)

${ }^{24}$ M. GaWLICKI, Odbudowa śródmieścia Gdańska w fotografii Kazimierza Lelewicza, [w:] Odbudowa. Fotografie..., s. 42.

${ }^{25}$ Wśród fotografów dokumentujących zniszczenia wojenne Gdańska byli m.in.: Stefan Arczyński, Jan Bułhak, Marian Dobrzykowski, Grzegorz Kanafocki, Tadeusz Wański i Edmund Zdanowski. 
Po latach archiwum artysty zawierało ogromną liczbę dokumentów fotograficznych o nieprzecenionej wartości historycznej, której zresztą fotograf był świadom, pisał bowiem:

Twórczość moja i działalność fotograficzno-artystyczna w Polsce Ludowej (...) polegała na opracowaniu dokumentacji artystycznej zniszczeń wojennych i odbudowy miasta Gdańska i Wojew. Gdańskiego, tj. architektury zabytkowej, dzieł sztuki, krajobrazu i nowo powstających osiedli w czasie odbudowy, budowy i po odbudowie. (...) W czasie od 1945 r. do 1974 r. wykonałem tysiące zdjęć fotograficznych w/w tematów cennych dla miasta i województwa gdańskiego. Z archiwum mojego korzystali i nadal w razie potrzeb korzystają Konserwatorzy miejski i wojewódzki w Gdańsku, Wydział Ochrony Muzeów i Zabytków Ministerstwa Kultury i Sztuki, Ministerstwo Spraw Zagranicznych i różne instytucje wydawnicze w Kraju i za granicą ${ }^{26}$.

Ideę gromadzenia trafnie analizuje Magdalena Wróblewska, wskazując, że nie ma idealnego archiwum, pozostaje ono zawsze projektem, a wręcz „jest niemożliwą do zrealizowania fantazją, w rzeczywistości bowiem pełne jest niekonsekwencji i pęknięć, zawieszone między utopijnym projektem a pracą pamięci"27. Tak też należałoby patrzeć na archiwum K. Lelewicza, szczególnie z perspektywy czasu, która powoduje owe „pęknięcia”, doprowadzając do przekonania o braku kompletności zbiorów.

Obecnie szacuje się zachowaną spuściznę K. Lelewicza obrazującą zniszczenia i odbudowę Gdańska na ponad 3 tys. zdjęćc ${ }^{28}$, jednak nie wszystko zachowało się do naszych czasów. Jerzy W. Wołodźko, przygotowując publikację na temat odbudowy Gdańska na podstawie zdjęć artysty, stwierdził, że wśród przeglądanych fotografii nie ma ujęć obiektów, w których znajdowały się Urząd Bezpieczeństwa, Komitet Wojewódzki PZPR czy Milicja Obywatelska. Następnie podał w wątpliwość, by fotograf bał się dokumentować tego rodzaju obiekty.

${ }^{26}$ AZPAF, Teczka osobowa nr 8, Działalność i twórczość fotograficzno-artystyczna od dnia 1 I 1926 r. do dnia 1 VI 1974 r., karty bez paginacji.

27 M. WRÓBLEWSKA, Ruina w archiwum, [w:] Sztuka w kulturze, zbiór rozpraw, red. J. JeSZKE, Poznań 2011, s. 226.

${ }^{28}$ Prace przedstawiające zniszczenia i odbudowę Gdańska autorstwa K. Lelewicza przechowują m.in.: Polska Akademia Nauk Biblioteka Gdańska, Muzeum Gdańska, Pomorski Wojewódzki Konserwator Zabytków w Gdańsku, Oddział Gdański Narodowego Instytutu Dziedzictwa, Fundacja Karrenwall, dodatkowo część zdjęć można oglądać w domenie publicznej: Odkrywaj dziedzictwo Gdańska, http://dziedzictwo-gdansk.pl/online-collection/-/results/init (dostęp: 20 XI 2020). 
Skłania się raczej do tezy, że zdjęcia zostały skonfiskowane przez służby bezpieczeństwa w latach pięćdziesiątych XX w., i dodaje, że znaczna część spuścizny po śmierci K. Lelewicza zniknęła w nieznanych dotąd okolicznościach ${ }^{29}$. Nie zabezpieczono archiwum, które zostało rozproszone ${ }^{30}$.

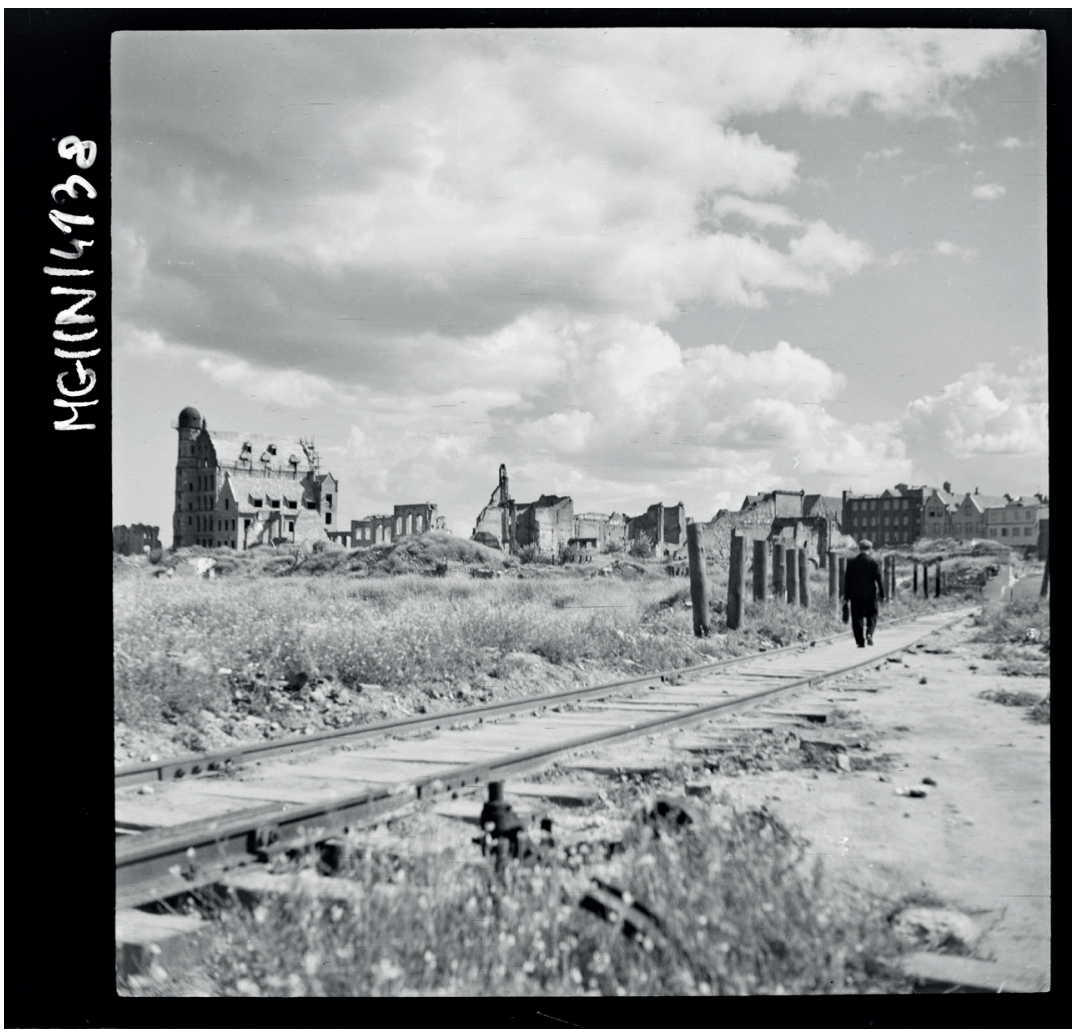

Ryc. 2. Negatyw czarno-biały ukazuje zrujnowany, pozbawiony zabudowy plac między ulicami św. Ducha a Mariacką w Gdańsku. Na pierwszym planie widoczne torowisko, po którym spaceruje mężczyzna. W centrum kadru trawiasty plac, za którym widoczne są zrujnowane gdańskie budowle, m.in. prawie doszczętnie zniszczona zabudowa ulicy Mariackiej, z widocznym domem Towarzystwa Przyrodniczego po lewej stronie. Czas powstania fotografii: po 1945 r., fot. Kazimierz Lelewicz, zbiory Muzeum Gdańska, numer inwentarzowy: MG/IN/4138 (źródło opisu: http:// dziedzictwo-gdansk.pl/record/-/record/display/manifestation/RECORD20209/43f04670-5e36-40ca-88c1-31e0495921cd/solr/0/12/0/1/score/DESC, dostęp: 18 X 2020)

${ }^{29}$ J.W. WoŁODŹKO, Wstęp, [w:] Odbudowa Wielkiej Zbrojowni w Gdańsku. Fotografie Kazimierza Lelewicza, red. J. DominicZAK, M. GAWLICKI, J.W. WoŁODŹKO, Gdańsk 2014, s. 21.

${ }^{30}$ Ponad 3 tysiace zdjęć i pocztówek dawnego Gdańska dostępnych online. Miasto na zdjęciach Kazimierza Lelewicza, https://dziennikbaltycki.pl/ponad-3-tysiace-zdjec-i-pocztowek-dawnego-gdanskadostepnych-online-miasto-na-zdjeciach-kazimierza-lelewicza/ar/c13-14752166 (dostęp: 20 XI 2020). 
Kazimierz Lelewicz jeszcze za życia zadbał, aby część dokumentacji fotograficznej trafiła do instytucji czuwających nad kulturą materialną. W latach siedemdziesiątych XX w. przekazał pozytywy do ówczesnych: Biblioteki Gdańskiej Polskiej Akademii Nauk i Muzeum Historii Miasta Gdańska. Biblioteka otrzymała dwie teki, każda po sto zdjęć ze szczegółowym wykazem prac i opracowaną graficznie przez K. Lelewicza stroną tytułową. Fotografik planował w sumie przygotować dziesięć tek, każda po sto zdjęćc ${ }^{31}$, ale ostatecznie zrealizował dwie. Pierwsza zawiera zdjęcia kościoła Mariackiego oraz ulic św. Ducha i Mariackiej. Druga gromadzi fotografie Ratusza Głównego i ul. Długiej. Fotografik zwracał uwagę, że dokumenty są „ważne dla konserwatora, inżyniera, budowniczych i artystów” 32 , ponieważ stanowią zapis „różnych ciekawych rozwiązań konstrukcyjnych dziś nie osiągalnych ze względu na odbudowane obiekty"33. Natomiast 20 marca 1973 r. muzeum na specjalnej uroczystości otrzymało w darze fotogramy składające się na wystawę pt. Gdańsk zniszczenie i odbudowa 1945-1970 ${ }^{34}$. Był to własnoręcznie przygotowany przez artystę zestaw 110 prac, a jego opracowywanie, jak twierdził, zajęło mu dwadzieścia lat ${ }^{35}$. Fotografik miał jeszcze w planach przekazać miastu dwie panoramy o wymiarach $110 \times 220 \mathrm{~cm}$ ukazujące zniszczenia oraz zamierzał wydać katalog ${ }^{36}$. Zanim K. Lelewicz przekazał w latach siedemdziesiątych XX w. swoje prace instytucjom nauki i kultury, jego zdjęcia dotyczące Gdańska były prezentowane na licznych wystawach pod charakterystycznymi tytułami: Wojna niszczy, pokój buduje oraz Zniszczenie i odbudowa Gdańska ${ }^{37}$.

${ }^{31}$ Kazimierz Lelewicz opracowywał jeszcze następujące teki: III (Długi Targ, Dwór Artusa, Zielona Brama i ul. Chlebnicka), IV (Zbrojownia), V (Długie Pobrzeże i Spichrze), a kolejne miał w planach, AZPAF, Teczka osobowa nr 8, Ankieta Kazimierz Lelewicz ur. 15 XII 1896 r. (lat 77) członek współzałożyciel ZPAF leg. nr 8 (EFIAP), karty bez paginacji.

${ }^{32}$ Ibidem.

33 Ibidem.

${ }^{34}$ Ibidem.

${ }^{35}$ Ibidem.

${ }^{36} \mathrm{Ibidem}$. Za życia K. Lelewicza nie ukazało się żadne monograficzne wydawnictwo z pracami artysty, poza jedynym ze zdjęciami Zamku w Malborku w związku z wystawą w 1962 r., Zamek Malborski w fotografice Kazimierza Lelewicza, [katalog wystawy], Malbork 1962.

37 W listopadzie 1950 r. z okazji II Kongresu Obrońców Pokoju zorganizowano w Muzeum Pomorskim w Gdańsku wystawę prac K. Lelewicza pod hasłem Wojna niszczy, pokój buduje. Prezentowano ponad 50 fotogramów pokazujących zniszczone i odbudowywane zabytki Gdańska i województwa gdańskiego. W następnych latach odbyły się wystawy K. Lelewicza pod tytułem Zniszczenie i odbudowa Gdańska, na których eksponowano zestawy zdjęć w różnych, zmiennych konfiguracjach, przygotowywanych przez samego autora. Kolejno były to: Wystawa z okazji Dni Gdańska w Dworze 


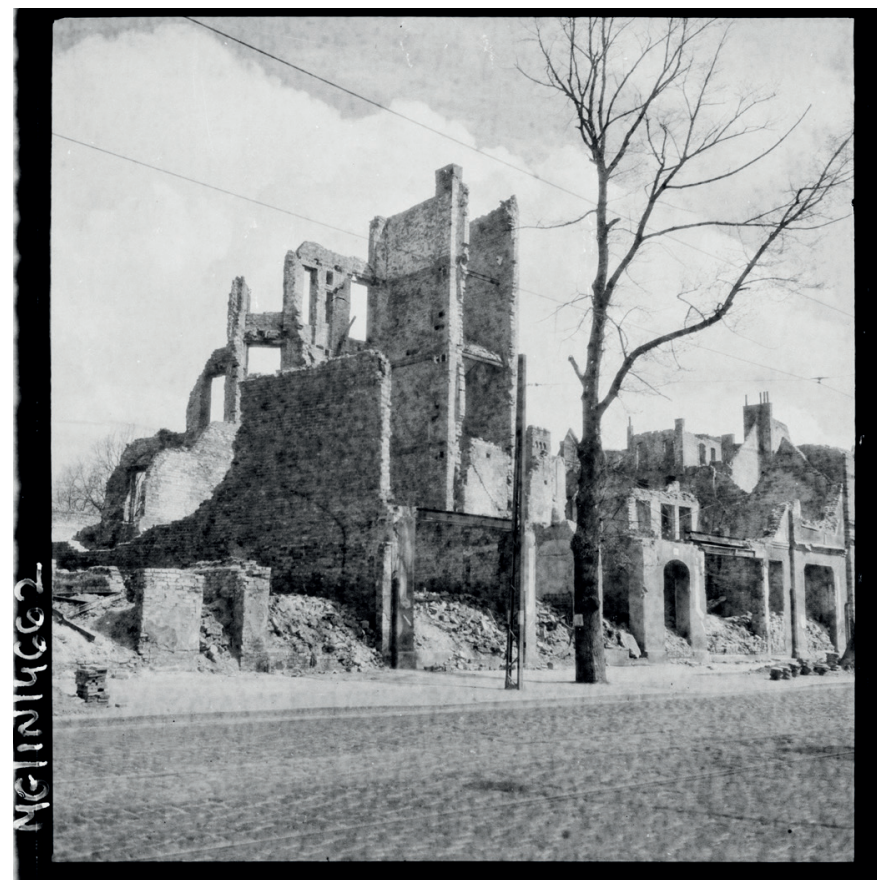

Ryc. 3. Negatyw czarno-biały ukazuje ruiny kamienic w Głównym Mieście w Gdańsku. Czas powstania fotografii: po 1945 r., fot. Kazimierz Lelewicz, zbiory Muzeum Gdańska, numer inwentarzowy: MG/IN/4662 (źródło opisu: http://dziedzictwo-gdansk.pl/record/-/record/display/manifestation/RECORD21255/6fbd974f-7c38-4a05-8cfb-bb973dba84c1/solr/0/12/0/1/score/DESC, dostęp: 18 X 2020)

Prezentacja archiwalnych zdjęć dokumentalnych w przestrzeniach muzealnych weszła w obszar sztuki, subwersja motywu ruiny spowodowała nowy proces zapisu i odbioru przeszłości. Dokonała się, cytując M. Wróblewską, „dekonstrukcja archiwum"38, przez wprowadzenie zdjęć do galerii uzyskano jeszcze większą siłę oddziaływania obrazu miasta-ruiny. W sztuce umarłe, obrócone w gruzy miasto (czy w ogóle obraz zniszczenia) paradoksalnie zdaje się bardziej fotogeniczne/malownicze niż miasto niezniszczone. Idea ruiny została spopularyzowana przez romantyzm ${ }^{39}$, ale powojenny obraz zniszczeń nabrał zupełnie innego

Artusa (1959); Wystawa w Ratuszu Głównym w Gdańsku (1960); Wystawa w Klubie TPPR w Gdańsku, potem przeniesienie wystawy do Leningradu i Warszawy (1961); Wystawa w Klubie Stowarzyszenia Architektów Polskich Odział w Gdańsku SARP (1962) i Wystawa w ramach Dni Kultury Polskiej w Szwecji (1968), Teczka osobowa, Archiwum ZPAF.

${ }^{38}$ M. WróBLEWSKA, op. cit., s. 232.

39 G. KRÓLIKIEWICZ, Terytorium ruin. Ruina jako obraz i temat romantyczny, Kraków 1993. 
wymiaru. Dla K. Lelewicza, artysty wywodzącego się z kręgu piktorialistów, aspekt sztuki miał ogromne znaczenie w prezentowanych pracach. Twierdzil, że negatyw jest tylko „punktem wyjścia, materiałem dalszego opracowania obrazu,

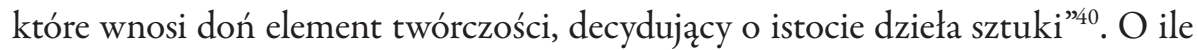
w wypadku malarstwa czy grafiki sfera emocjonalna jest odwzorowaniem wizji artysty, o tyle w fotografii staje się to trudniejsze do przekazania, ponieważ specyfika medium polega przede wszystkim na rejestracji, oczywiście jeśli nie będziemy ingerować w sam materiał fotograficzny. Temat ruin przez swoje uwarunkowania historyczno-artystyczne został bardzo szybko zaanektowany przez fotografów deklarujących swoje związki z tradycją malarską ${ }^{41}$.

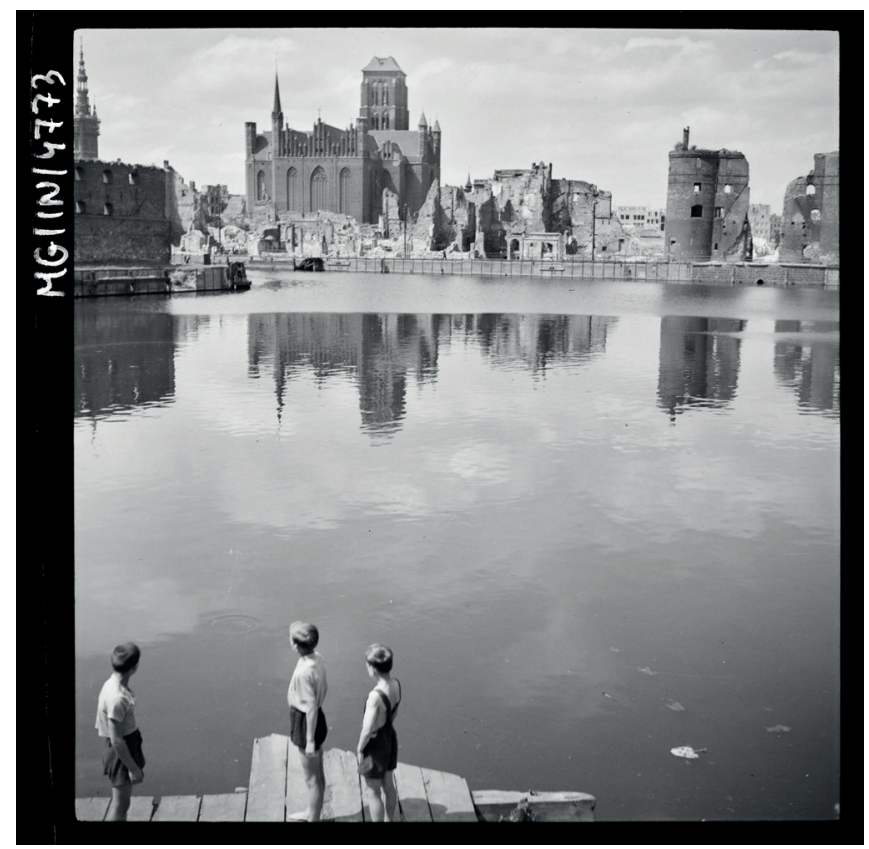

Ryc. 4. Negatyw czarno-biały ukazuje widok na ruiny zabudowań przy Długim Pobrzeżu - ujęcie z perspektywy ulicy Szafarnia. U dołu kadru trzej mężczyźni [chłopcy - A.P.] zwróceni w kierunku Motławy, która obejmuje większość kadru. Na dalszym planie Długie Pobrzeże z ruinami żurawia po prawej stornie. W tle kościół Mariacki z odbudowanym dachem. Po lewej fragment Wyspy Spichrzów z ruinami spichlerza. Czas powstania fotografii: po 1945 r., fot. Kazimierz Lelewicz, zbiory Muzeum Gdańska, numer inwentarzowy: MG/IN/4773 (źródło opisu http://dziedzictwogdansk.pl/record/-/record/display/manifestation/RECORD21475/4de2e30a-9ec0-48aa-9859-cd2ebc6cf1eb/solr/0/12/0/1/score/DESC, dostęp: 18 X 2020)

40 L. Grabowski, Kazimierz Lelewicz, „Fotografia” 1958, nr 6, s. 276.

${ }^{41}$ M. Szymanowicz, Zaburzona epoka..., s. 84. 
Fotogramy K. Lelewicza cechuje precyzyjna i wystudiowana kompozycja, często diagonalna, nadająca dynamizmu. Niejednokrotnie był wykorzystywany przez artystę motyw obramowania zamykający kompozycję jak rama obrazu. Ostre rysy ruin kontrastują z miękkimi kształtami chmur. Nasuwa to skojarzenia z malarstwem symbolizmu i Młodej Polski. Doskonały warsztat fotografa pozwalał mu na wykonywanie zdjęć pod światło; w skrajnych zestawieniach tonalnych, od jasnych do ciemnych, nadal widzimy detale i elementy obrazu. Wydaje się, że świadomie wybierał słoneczne dni, by odwzorować na fotografii tę niesamowitą grę cieni i świateł, co z perspektywy rzetelnego zapisu "prawdy” nie jest zgodne z wymogami fotografii dokumentalnej. W sposób przemyślany wybierał motywy zdjęcia, które miały wpływać na nastrój obrazu. Uczucie pustki i przygnębienia potęgowały samotne drzewa, czasem uschnięte, a także pojedyncze, przemykające wśród ruin postaci oraz ciężko wiszące nad resztkami zabudowań chmury. Sam artysta wypowiadał się na temat sztuki fotograficznej następująco: „Chodzi bowiem o to, by rozwijać umiejętności techniczne i możliwości estetycznego widzenia równomiernie. Uważam, że fotografia artystyczna nazwana fotografiką jest sztuką"².

Wywoływanie uczucia melancholii i nostalgii nie sprzyjało ukazywaniu rzeczowego obrazu ruin w myśl zasady fotografii dokumentalnej, w której dominuje wstrzemięźliwość interpretacyjna rejestrowanego obrazu. Badacz polskiej fotografii artystycznej M. Szymanowicz podkreśla, że twórcy z tego środowiska bardzo często skupiali się na potencjale symbolicznego motywu ruin, w efekcie prowadziło to do „zakłócenia” identyfikacji miejsca i jego topograficznego położenia ${ }^{43}$. Kazimierz Lelewicz dokumentował zastany obraz miasta od szerokich kadrów po detal. Szczególnie przy detalach widoczne jest, jak to nazywał Jacek Friedrich, „celebrowanie polskości”ł4 (co miało wydźwięk propagandowy) w kreowaniu miejsca na nowo. Fotograf, pokazując zbliżenia orła polskiego, elementów władzy królewskiej czy herbu miasta, a także detali architektonicznych związanych ze stylami takimi jak gotyk, renesans i barok, wpisywał się w retorykę władzy mówiącej, że Gdańsk od wieków należał do państwa polskiego. Pisał m.in., charakteryzując powojenne miasto: „Ulica Gdańska w swych kamiennych zabytkach była i pozostała polska, przetrwała rozbiory, przetrwała

\footnotetext{
42 L. GRABOWSKI, op. cit., s. 274.

43 M. SZYMANOWICZ, Zaburzona epoka..., s. 85.

44 J. FRIEDRICH, op. cit., s. 58.
} 
ostatnią okupację; łatwiej było sprusczyć jej mieszkańców, niż zniszczyć jej mury. A i sama architektura gdańska nie była bynajmniej architekturą niemiecką ${ }^{35}$.

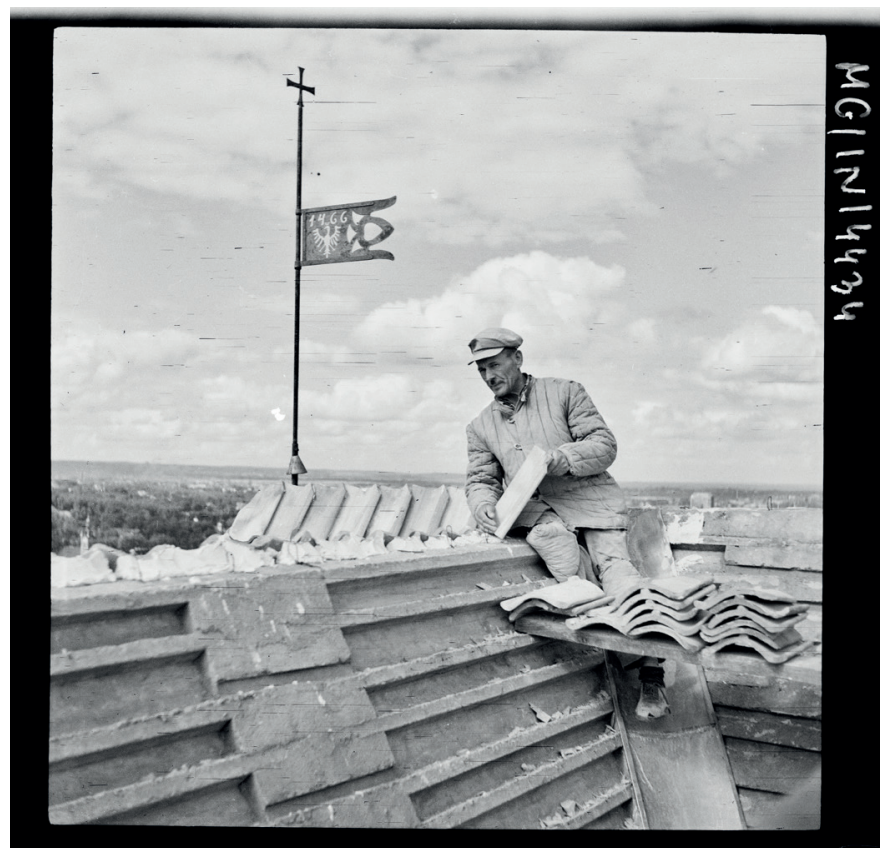

Ryc. 5. Negatyw czarno-biały ukazuje dekarza podczas układania dachówki. Czas powstania fotografii: po 1945 r., fot. Kazimierz Lelewicz, zbiory Muzeum Gdańska, numer inwentarzowy: MG/ IN/4434 (źródło opisu http://dziedzictwo-gdansk.pl/record/-/record/display/manifestation/ RECORD20799/90e7680b-9b59-4543-b361-002a95a9f2bd/solr/0/12/0/1/score/DESC, dostęp: $20 \times 2020$ )

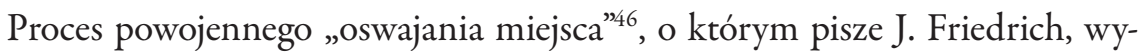
magał zaangażowania wielu sił, by nowi mieszkańcy Gdańska mentalnie i fizycznie zaakceptowali swoje położenie. Starano się pokazać miasto z ogromnym potencjałem, wykorzystywano przy tym piastowskie korzenie i akcenty morskie, uświadamiając Polakom ówczesną sytuację, że oto buduje się silne państwo z rozwijającą się gospodarką morską. Posługiwano się np. patriotyczną frazeologią. Z okazji Święta Morza w 1947 r. wiceprezydent Gdańska Jerzy Trediakowski mówił o powrocie na „prastary szlak piastowski”7, który „łączy szeregiem

\footnotetext{
45 K. LELEWICZ, op. cit., s. 279.

${ }^{46}$ J. FRIEDRICH, op. cit., s. 55-81.

${ }^{47}$ (t), Obchód „Święta Morza” w Gdańsku, „Dziennik Bałtycki” 1947, nr 177 (30 VI), s. 2.
} 
arterii” ${ }^{\$ 8}$ Wybrzeże z centrum Polski, a „Gdańsk, Sopot i Gdynia to przedłużenie Marszałkowskiej z Warszawy i Piotrkowskiej z Łodzi”9 Podobną retorykę o piastowskich korzeniach miasta stosował sam K. Lelewicz, pisząc: „Pustka, która powiała od ruin, nie przestraszyła dążących ku morzu piastowskim szlakiem Polaków"50. Artysta z jednej strony brał udział w budowaniu mitu polskości Gdańska, z drugiej strony kreował wizerunek nowego, socjalistycznego państwa. Dobrze to widać na zdjęciach, w których uchwyceni zostali ludzie przebywający wśród ruin. Zmysł dokumentalisty został połączony z kreacją, niektóre sceny, szczególnie te kameralne, sprawiają wrażenie wyreżyserowanych. Uczucia towarzyszące bacznemu obserwatorowi, od przygnębienia, osamotnienia i strachu, przez nadzieję, po zapał i wiarę, zostały zarejestrowane na kliszy. Zdjęcia nie mają jeszcze znamion doktryny socrealizmu ${ }^{51}$, natomiast widać w nich rozmach, czuć energię miasta odbudowanego przez nowo przybyłych mieszkańców. Zatrzymując się na chwilę przy powojennej społeczności miasta, zwróćmy uwagę, że społeczeństwo tworzyło się od podstaw w oparciu o polskie osadnictwo, przesiedlenia ludności niemieckiej i weryfikację autochtonów $^{52}$. Prowadziło to do wyjątkowo długiego procesu budowania tożsamości gdańszczan ${ }^{53}$.

Ekspozycje prac K. Lelewicza z okresu od lat pięćdziesiątych do siedemdziesiątych XX w., pokazujące miasto w ruinie i miasto odbudowane, stawały się symboliczne i miały istotne znaczenie w podtrzymywaniu myślenia wspólnotowego i budowania pamięci zbiorowej, o której pisze Barbara Szacka ${ }^{54}$. Autorka zwraca uwagę, że „Pamięć zbiorowa jest zbiorem symboli”" ${ }^{2}$, i dodaje: „Symbole te tworzą specyficzny «język» grupy, który staje się jednym z jej wyróżników, a umiejętność posługiwania się nimi czyni osobnika pełnoprawnym jej członkiem. Istnienie tego języka wzmacnia poczucie wspólnoty używających go lu-

${ }^{48}$ Ibidem.

49 Ibidem.

${ }^{50}$ K. LELEWICZ, op. cit., s. 279.

51 M. JuRECKA, Socrealizm w fotografii, „Sztuka” 1988, nr 5-6, s. 55-61.

52 J. FRIEDRICH, op. cit., s. 55-81; M. HeJGER, Kwestia narodowościowa na tle przeksztatceń ludnościowych w Gdañsku po zakończeniu dziatań wojennych, [w:] Gdańsk 1945..., s. 87-117.

53 S. BYKOWSKA, Między communitas a struktura - początki spoteczności gdańskiej po 1945 r., [w:] Tożsamość Gdańszczan. Budowanie na (nie)pamięci, red. M. Mendel, A. ZBIERZCHOwSKA, Gdańsk 2010, s. 125-147.

${ }^{44}$ B. SzACKa, Czas przeszty. Pamięć. Mit, Warszawa 2006, s. 50-51.

55 Ibidem, s. 50. 
dzi i uświadamia im, że są inni niż ci, którzy go nie znają i nie rozumieją" Fotografie K. Lelewicza stały się kodem rozumianym najlepiej przez powojennych mieszkańców Gdańska, którzy zobaczyli obraz zniszczenia i uczestniczyli w odbudowie miasta, połączyła ich wspólna historia.

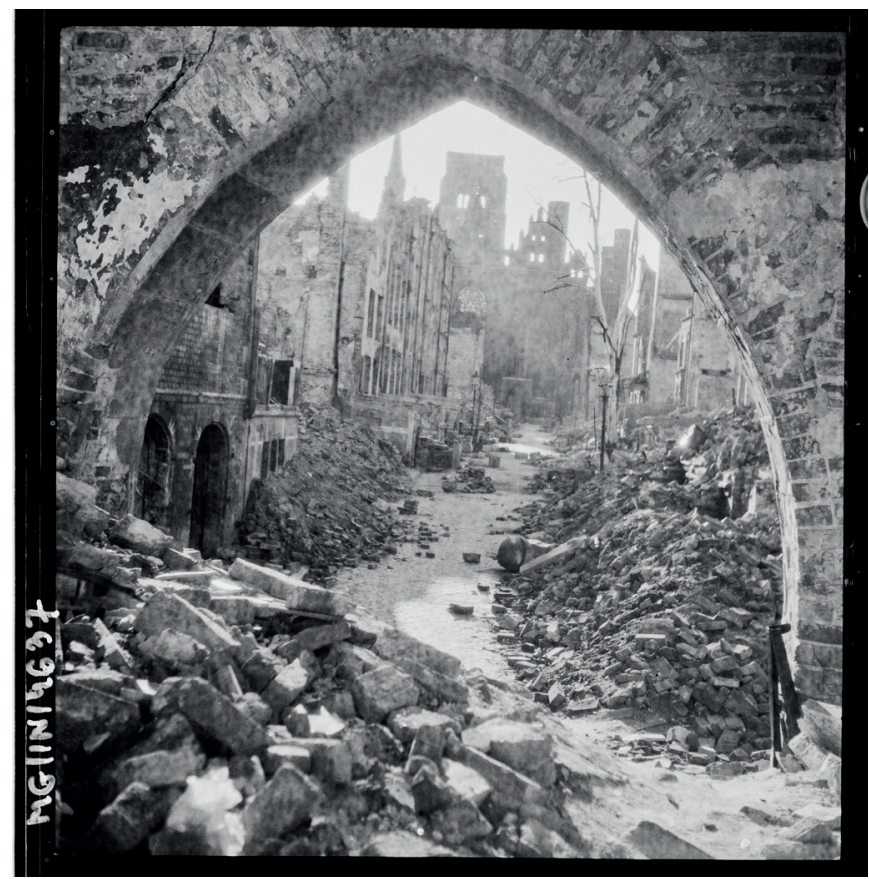

Ryc. 6. Negatyw czarno-biały ukazuje gruzowisko i ruiny zabudowań przy ulicy Mariackiej w Gdańsku - ujęcie z przejazdu bramnego bramy Mariackiej. Na pierwszym planie sterta gruzu. Czas powstania fotografii: po 1945 r., fot. Kazimierz Lelewicz, zbiory Muzeum Gdańska, numer inwentarzowy: MG/IN/4637 (źródło opisu http://dziedzictwo-gdansk.pl/record/-/record/display/ manifestation/RECORD21205/1ded9439-1d43-4f2e-b77c-58ce4f51e299/solr/0/12/0/1/ score/DESC, dostęp: 18 X 2020)

Jest jeszcze jedna wartość zdjęć K. Lelewicza. W 1945 r. dziewiętnastowieczna, historyzująca i eklektyczna zabudowa Gdańska nie miała walorów dzieła sztuki z punktu widzenia ochrony konserwatorskiej j7. Jako niemiecka musiała zostać w sposób fizyczny i symboliczny wyparta ze świadomości Polaków, tak by w ogólnonarodowym postrzeganiu miasto zajęło właściwe według ówczesnych władz miejsce na geopolitycznej mapie. Na fotografiach

\footnotetext{
${ }^{56}$ Ibidem, s. 51.

57 M. GAWLICKI, Zabytkowa architektura..., s. 24.
} 
K. Lelewicza zostały zapisane fragmenty bądź też nieliczne całe budowle, które w procesie rekonstrukcji i odbudowy rozebrano do poziomu fundamentów, a tym samym przestały istnieć. W ich miejsce stawiano często socrealistyczne bloki mieszkalne $\mathrm{z}$ atrapami fasad w stylach historyzujących. W stosunku do Gdańska nie można mówić o poczuciu straty w społeczności na przykładzie budowli architektonicznych, o którym wspomina M. Wróblewska, opisując zdjęcia utraconych budynków Warszawy autorstwa Leonarda Sempolińskiego ${ }^{58}$.

W Gdańsku nie została zachowana ciągłość historyczna społeczeństwa sprzed katastrofy i po niej. Kazimierz Lelewicz, choć pamiętał miasto sprzed wojny, patrzył na ruiny Gdańska z dystansu, jego stosunek emocjonalny skupiał się na utracie zabytków architektury, a nie miasta jako takiego. Pytając: „Kiedy my ten Gdańsk odbudujemy?”`99, utożsamiał się z tym miastem jako osoba wykształcona w kierunku artystycznym, zdolna ocenić poniesioną stratę. Dzięki temu, że fotograf miał również wykształcenie w kierunku historii sztuki, jego postrzeganie miasta skupiało się wokół najważniejszych, historycznych budowli, które przypisywał kolejnym epokom. Stosowana przez artystę wybiórczość zakłamuje obraz zniszczeń. Zdjęcia archiwalne K. Lelewicza, które przyjęły w pełni konwencję dokumentu, zachowują rys estetyki i emocji towarzyszący sztuce. Nie pozwala to zakwalifikować owych prac do obiektywnej prawdy. Jest to prawda widziana oczami artysty, jego wizja historii podyktowana subiektywnymi wyborami.

\section{BIBLIOGRAFIA}

\section{Źródła archiwalne}

Archiwum Państwowe w Gdańsku

Sprawozdanie GDO za okres 1 maja 1945 - 1 września 1946, 1180/12

Archiwum Politechniki Gdańskiej

Ankieta personalna Kazimierz Lelewicz.

Archiwum Związku Polskich Artystów Fotografików

Teczka osobowa Kazimierz Lelewicz nr 8.

\footnotetext{
58 M. WRÓBLEWSKA, op. cit., s. 225.

59 K. LELEWICZ, op. cit., s. 281.
} 


\section{Opracowania}

(t), Obchód „Święta Morza”w Gdańsku, „Dziennik Bałtycki” 1947, nr 177 (30 VI).

Bułhak J., Fotografia ojczysta. Rzecz o uspotecznianiu fotografii, Wrocław 1951.

Bykowska S., Między communitas a strukturq - początki spoteczności gdańskiej po 1945 r., [w:] Tożsamość Gdańszczan. Budowanie na (nie)pamięci, red. M. Mendel, A. Zbierzchowska, Gdańsk 2010, s. 125-147.

Ciemnołoński J., Kręte drogi Kazimierza Lelewicza do rumowiska Gdańska, „Z Historii Politechniki Gdańskiej...” 1995, nr 4, s. 18-23.

Daniszewski T., Kazimierz Lelewicz (1896-1986), „Kalendarz Gdański na Rok 1989”, Gdańsk 1988, s. 174-177.

Domke R., Ziemie Zachodnie i Pótnocne Polski w propagandzie lat 1945-1948, Zielona Góra 2010.

Fotografowie 1946-2006. Stownik biograficzny fotografów polskich (cztonków ZPAF), red. Z. Jurkowlaniec, W.T. Nowotka, M. Wideryński, Warszawa 2006.

Friedrich F., Odbudowa Gtównego Miasta w Gdańsku w latach 1945-1960, Gdańsk 2015.

Gawlicki M., Odbudowa śródmieścia Gdańska w fotografii Kazimierza Lelewicza, [w:] Odbudowa. Fotografie Kazimierza Lelewicza, red. J. Dominiczak, M. Gawlicki, J.W. Wołodźko, Gdańsk-Toruń 2014, s. 37-43.

Gawlicki M., Zabytkowa architektura Gdańska w latach 1945-1951. Ksztattowanie koncepcji konserwacji i odbudowy, Gdańsk 2012.

Grabowski L., Kazimierz Lelewicz, „Fotografia” 1958, nr 6, s. 273-278.

Gruszkowski W., Zniszczenie Śródmieścia Gdańska ipoczątki odbudowy, [w:] Gdańsk 1945. Materiaty z sesji naukowej odbytej $w$ dniu 30 marca 1995 r., pod red. prof. dr. hab. Mariana Mroczki, red. E. Rusak, Gdańsk 1995, s. 19-26.

Hejger M., Kwestia narodowościowa na tle przeksztatceń ludnościowych w Gdańsku po zakończeniu dziatań wojennych, [w:] Gdańsk 1945. Materiaty z sesji naukowej odbytej w dniu 30 marca 1995 r., pod red. prof. dr. hab. Mariana Mroczki, red. E. Rusak, Gdańsk 1995, s. 87-117.

Hewelt W., Danzig, ein europäisches Kulturdenkmal, Lübeck 1988.

Jasiński J., Kwestia pojęcia Ziemie Odzyskane, [w:] Ziemie Odzyskane - Ziemie Zachodnie i Pótnocne 1945-2005. 60 lat w granicach państwa polskiego, red. A. Sakson, Poznań 2006, s. 15-25.

Jurecka M., Socrealizm w fotografii, „Sztuka” 1988, nr 5-6, s. 55-61.

Królikiewicz G., Terytorium ruin. Ruina jako obraz i temat romantyczny, Kraków 1993.

Kula M., Między przesztościa a przysztością. O pamięci, zapominaniu i przewidywaniu, Poznań 2004.

Lelewicz K., Wojnq wielkość karleje - pokojem wzrasta, „Kalendarz Gdański na Rok 1985”, Gdańsk 1984, s. 279-284. 
Odbudowa. Fotografie Kazimierza Lelewicza, red. J. Dominiczak, M. Gawlicki, J.W. Wołodźko, Gdańsk-Toruń 2014.

Okoniewska B., Refleksje nad rokiem 1945, [w:] Gdańsk 1945. Materiaty z sesji naukowej odbytej w dniu 30 marca 1995 r., pod red. prof. dr. hab. Mariana Mroczki, red. E. Rusak, Gdańsk 1995, s. 7-17.

Piwowarski J., Fotoklub Polski (1929-1939), [w:] IX Międzynarodowe Targi Fotografii i Obrazu XIII Ogólnopolski Zjazd Fotografów. Materiaty sesji naukowo-technicznej, POLFOTO'2000, Międzyzdroje, 4-9 kwietnia 2000 r., red. P. Nowak, Wrocław 2000, s. $147-154$.

Piwowarski J., Wileńskie środowisko fotograficzne w okresie międzywojennym, Częstochowa 2016.

Plater-Zyberek M., Dreścik G., Kalendarium, [w:] Jan Buthak (1876-1950) fotografik, [katalog wystawy Muzeum Narodowe w Warszawie, 14 grudnia 2006 - 11 lutego 2007], red. D. Jackiewicz, A. Masłowska, Warszawa 2007, s. 21-127.

Prodger P., Impressionist Camera. Pictorial Photography in Europe, 1888-1918, London 2006.

Przeździecka-Kujałowicz A., „Warszawa oskarża”. Pierwsza powojenna wystawa Muzeum Narodowego w Warszawie, "Spotkania z Zabytkami. Kultura, Tradycje, Pamiątki” 2018, nr 11-12, s. 24-31.

Rosenblum N., A World History of Photography, New York-London 1997.

Sobota A., Jan Buthak i koncepcje narodowości fotografii, [w:] Jan Buthak (1876-1950) fotografik, [katalog wystawy Muzeum Narodowe w Warszawie, 14 grudnia 2006-11 lutego 2007], red. D. Jackiewicz, A. Masłowska, Warszawa 2007, s. 176-197.

Sobota A., Szlachetność techniki. Artystyczne dylematy fotografii w XIX i XX wieku, Warszawa 2001.

Stankiewicz J., Szermer B., Gdańsk. Rozwój urbanistyczny i architektoniczny orazpowstanie zespotu Gdańsk-Sopot-Gdynia, Warszawa 1959.

Stryczyński M., Gdańsk w latach 1945-1948. Odbudowa organizmu miejskiego, Gdańsk 1981.

Szacka B., Czas przeszty. Pamięć. Mit, Warszawa 2006.

Szymanowicz M., Budowniczowie "Świata Fotografii”. Polska fotografia drugiej potowy lat 40. XX wieku, [katalog wystawy, maj-czerwiec 2009, Centrum Kultury „Zamek” w Poznaniu], Poznań 2009.

Szymanowicz M., Byliśmy jesteśmy będziemy. Fotografia ojczysta po II wojnie światowej, [w:] Interpretowaćfotografie. Materiaty z sesji naukowej zorganizowanej przez Oddziat Warszawski Stowarzyszenia Historyków Sztuki i Fundacje „Ars Auro Prior”, red. M. Wróblewska, Z. Jurkowlaniec, Warszawa 2009, s. 127-139.

Szymanowicz M., W kregu fotografii piktorialnej, [w:] Jan Buthak (1876-1950) fotografik, [katalog wystawy Muzeum Narodowe w Warszawie, 14 grudnia 2006 - 11 lutego 2007], red. D. Jackiewicz, A. Masłowska, Warszawa 2007, s. 128-175. 
Szymanowicz M., Zaburzona epoka. Polska fotografia artystyczna w latach 1945-1955, Poznań 2016.

Warszawa oskarża. Przewodnik po wystawie urzadzonej przez Biuro Odbudowy Stolicy wespót z Muzeum Narodowym w Warszawie [maj-czerwiec 1945, Warszawa], Ministerstwo Kultury i Sztuki i Ministerstwo Odbudowy Kraju, Warszawa 1945.

Warszawa 1945 w fotografii Leonarda Sempolińskiego, [katalog wystawy, Zachęta Centralne Biuro Wystaw Artystycznych, wrzesień 1969, Warszawa], red. B. Mitschein, Warszawa 1969.

Wołodźko J.W., Wstęp, [w:] Odbudowa Wielkiej Zbrojowni w Gdańsku. Fotografie Kazimierza Lelewicza, red. J. Dominiczak, M. Gawlicki, J.W. Wołodźko, Gdańsk 2014, s. 21.

Wróblewska M., Ruina w archiwum, [w:] Sztuka w kulturze, zbiór rozpraw, red. J. Jeszke, Poznań 2011, s. 223-232.

Wystawa Sztuk Plastycznych, [katalog wystawy, 27 VI - 15 VIII 1948, Sopot], Sopot 1948.

Zamek Malborski w fotografice Kazimierza Lelewicza, [katalog wystawy], Malbork 1962.

\section{Netografia}

Ciemnołoński J., Borowski Jan, [w:] Polski Stownik Biograficzny Konserwatorów Zabytków, http://www.serwer1363362.home.pl/SKP/ (dostęp: 20 XI 2020).

Historia powstania Związku Polskich Artystów Fotografików, https://zpaf.pl/wladzenaczelne/zalozyciele/ (dostęp: 20 XI 2020).

Kilarski M., Kilarski Jan, [w:] Polski Stownik Biograficzny Konserwatorów Zabytków, http://www.serwer1363362.home.pl/SKP/ (dostęp: 20 XI 2020).

Odkrywaj dziedzictwo Gdańska, http://dziedzictwo-gdansk.pl/online-collection/-/results/ init (dostęp: 20 XI 2020).

Ponad 3 tysiace zdjęć i pocztówek dawnego Gdańska dostępnych online. Miasto na zdjęciach Kazimierza Lelewicza, https://dziennikbaltycki.pl/ponad-3-tysiace-zdjec-i-pocztowek-dawnego-gdanska-dostepnych-online-miasto-na-zdjeciach-kazimierza-lelewicza/ar/ c13-14752166 (dostęp: 20 XI 2020).

\section{Anna Polańska}

\section{"CITY-RUIN". THE IMAGE OF THE POST-WAR GDAŃSK IN THE PHOTOGRAPHS OF KAZIMIERZ LELEWICZ}

Summary. Metropolises and cities have always fascinated artists, including those who use photography. World War II brought a hitherto unknown image of the city-ruins. Those who survived the annihilation made an attempt to depict the destruction. The photographs were supposed to be a testimony of the cruelty of war, and years later they also became material 
used by researchers from many scientific disciplines. Here emerges the specificity of showing the ruins in the context of a photo, which can be a document, but also a piece of art. The ruins became a journalistic and artistic challenge for the creators. Images of the destroyed cities began to be exhibited in museums and galleries, not only in the first years after the end of World War II. In Poland, the way of showing the devastation of Warsaw is symptomatic compared to the cities in the Recovered Territories. The capital has become a symbol of the drama of the whole country. The image of the city from before 1939 was often compared with the image of war damage. The photographs of the ruined: Gdańsk, Szczecin and Wrocław, had a slightly different message. In these cities, they looked for evidence of Polish identity, a centuries-old tradition and historical belonging to the Polish state. The views of the destroyed cities were juxtaposed with the image of the country's reconstruction, emphasizing the new geopolitical order. It is estimated that ninety percent of the historic center of Gdańsk was destroyed during World War II. In the fall of 1945, Kazimierz Lelewicz (1896-1986), an engineer and artist-photographer by education, came to such a ruined city. He began a long process of documenting the destruction and reconstruction of Gdańsk. What is striking in Lelewicz's photographs is the juxtaposition of the image of a city-ruin, an extinct, autonomous space, with a city-building, full of life. This combination of images of the urban tissue has a very symbolic and allegorical meaning. In this context, the image of the ruin and the way it was interpreted by Kazimierz Lelewicz is also worth considering. The topic itself provokes the consideration of the theme of ruin in the discourse of memory or oblivion.

Keywords: Kazimierz Lelewicz, destruction and reconstruction of Gdańsk, photography of ruins, city after the Second World War 